\title{
"If I am ill may God save me from being nursed by the ideal nurse that report sets up": The debate over an international standard in nursing education, 1917-1925.
}

Jaime Lapeyre

jaimelapeyre@gmail.com

Follow this and additional works at: https://qane-afi.casn.ca/journal

Part of the History of Science, Technology, and Medicine Commons, and the Public Health and Community Nursing Commons

\section{Recommended Citation}

Lapeyre, Jaime (2020) "'If I am ill may God save me from being nursed by the ideal nurse that report sets up": The debate over an international standard in nursing education, 1917-1925.," Quality Advancement in Nursing Education Avancées en formation infirmière: Vol. 6: Iss. 2, Article 6.

DOI: https://doi.org/10.17483/2368-6669.1214

This Article is brought to you for free and open access by Quality Advancement in Nursing Education - Avancées en formation infirmière. It has been accepted for inclusion in Quality Advancement in Nursing Education - Avancées en formation infirmière by an authorized editor of Quality Advancement in Nursing Education - Avancées en formation infirmière. 
Contemporary struggles in nursing education, including debates on jurisdiction over program approval, competency-based education, and curricula, are not new conversations among nurse leaders. Discussions on these very topics, spanning international borders, occurred between 1917 and 1925, as US nurse leaders looked to extend their influence over nursing education throughout the world. Elisabeth Crowell, an American nurse who was stationed in France with the Rockefeller Foundation's (RF) Commission for the Prevention of Tuberculosis in France (CPTF) worked towards improving nursing education in areas of France in 1917; however, similar changes to nursing education made by American nurse leaders working in the United States at this same time, led to conflict over the proper method of improving nursing education worldwide. This paper examines changes to nursing education during the early 20th century and explores the conflict and tensions that then existed regarding the setting of one single international standard in nursing education.

In response to the public health emergency in the wake of World War I, CPTF commenced a program to train health visitors in order to staff their newly established tuberculosis dispensaries in France. As part of its work, the CPTF established several health centres, staffed largely by local tuberculosis workers and visiting nurses. To ensure a steady supply of trained personnel for the Commission's tuberculosis dispensaries, the Commission set out to investigate methods for the training of health visitors (Embree, 1918). ${ }^{1}$ The nurse placed in charge of the health visitor program under the Commission was (Frances) Elisabeth Crowell. Crowell was a Catholic American nurse who graduated from the first class of St. Joseph's (Catholic) Hospital Training School for Nurses in Chicago in 1895. Following graduation, Crowell moved to Florida and founded a training school for nurses at St. Anthony's Hospital. She later moved to New York and attended the New York School of Philanthropy (now the Columbia University School of Social Work) before becoming a special investigator for the Association of Neighborhood Workers in New York City (Bullough \& Sentz, 2000). Her familiarity with visiting and public health nursing in the United States was enhanced through her extensive studies of midwifery between 1906 and 1917, as well as by her time as executive secretary of the Association of Tuberculosis Clinics in New York City (Rockefeller Foundation, 1921).

As one of her first tasks with the CPTF, Crowell undertook a survey of health visiting, evaluating several nurse training facilities in Paris (Bureau of Public Health Visiting, 1921). With France's devastating losses during the war, including millions killed and wounded and millions more who contracted tuberculosis and other infectious diseases, the postwar period marked an unprecedented public interest in the physical health and well-being of French citizens. In response, the government enlisted hundreds of nurses and volunteer visitors to teach domestic hygiene and the methods of proper infant and child care (Schultheiss, 2001, p. 6). In addition to these government initiatives, numerous individuals, private institutions, and organizations, both national and international, sponsored public health and social hygiene projects. ${ }^{2}$ Historian Katrin

\footnotetext{
${ }^{1}$ For a critical account of the CPTF, see Murard and Zylberman (2000).

${ }^{2}$ Similar initiatives were also begun in Britain during World War I. After a call to volunteer, nearly three million women engaged in war work with the British Red Cross. Voluntary Aid Detachment (VAD) units were mobilized, organized, and paid through the British Red Cross and attached to military and camp hospitals to assist with the care of the sick and wounded. During the War, 80,000 women completed first aid and home nursing certificates to become VADs or FANYs (First Aid Nursing Yeomanry). Nursing "sisters," that is, trained nurses who were also engaged in the war-relief effort, were anxious that the VADs would not be confused with sisters and ordered them to wear their caps in a different way, tying them behind their head. Considerable controversy raged over what the
} 
Schultheiss (2001, p. 146) has argued that when the Armistice was signed in November 1918, most volunteer nurses had no intention of continuing in nursing and quickly abandoned the profession; they had simply wanted to contribute to the war effort. Some Red Cross nurses, however, had substantial training and years of nursing experience before the war and wanted to remain in their role at the bedside (Schultheiss, p. 167). ${ }^{3}$ Crowell had received numerous applications for employment with the Commission from French Red Cross nurses who had gained considerable experience in military hospitals during the war. To meet the immediate emergency, despite not yet having a definite plan for training health visitors, the Commission decided to accept the most promising of these applicants and to give them, as best they could, the necessary training in dispensary and home visiting work while they served as members of the Commission's dispensary staff (Commission for the Prevention of Tuberculosis in France, 1919). Like her colleagues in the United States, Crowell was also critical of the training program under the French Red Cross, later stating that these programs were unable to meet the required standards for training schools in place in France (Division of Public Health Visiting, 1920).

Upon completion of her survey, Crowell concluded that there were no trained health workers then available in France (Bureau of Public Health Visiting, 1921). Furthermore, Crowell argued, the institutions available for the practical training of such workers were wholly inadequate both in their organization and in the instruction provided (Commission for the Prevention of Tuberculosis in France, 1919). In an effort to propose an improvement to the training of health visitors, Crowell noted that, in the United States, it had been suggested that in certain areas of work (e.g., tuberculosis work and child welfare), health visitors were not required to be fully trained nurses. The view expressed was that the full technical training of the nurse was not essential for the educational, prophylactic, supervisory work of the health visitor (Commission for the Prevention of Tuberculosis in France, 1919). This standard also followed the practice then in place in England, where short courses had been established for women to obtain certificates or diplomas in health visiting since the early 20th century. Crowell also commented that the decision not to require fully trained nurses for the role of health visiting offered her a practical solution to the problem presented by the dearth of fully trained French nurses and provided for a fairly rapid recruitment of a much needed personnel (Commission for the Prevention of Tuberculosis in France, 1919).

Crowell's reliance on the existing ranks of women with nursing experience was the result of several factors in France. First, the great degree of central state control over social welfare and education placed constraints on the autonomy of voluntary agencies and limited women's access to professional education. Furthermore, other professions, such as medicine, remained protective of their professional boundaries, limiting the role of nurses in the community. According to Schultheiss (2001, p. 184), in France, a visiting nurse could enter a patient's home only on the recommendation of a physician. Consequently, Crowell believed the Red Cross nurses were the only women who were available for training and who had obtained experience in hospitals during the war:

\footnotetext{
VADs should be called. (See "What Is a Nurse?" 1914-1915). For more on the British VAD nurses see Donner (1997), Braybon and Summerfield (1987), and Summers (1988).

${ }^{3}$ Schultheiss has pointed out that some Red Cross nurses had served in Morocco in 1908 and 1911 and aided Parisian flood victims in 1910. Following these experiences, these nurses often went to work on hospital wards or in a dispensary. Although this level of experience was probably not typical of Red Cross nurses, the few available records that document the lives of some of these women suggest that these were not unique examples.
} 
The professional trained nurses who are available for private nursing are so few in number as to be practically a negligible quantity. Is it not significant that when recently a private hospital for the care of medical and surgical cases was opened in Paris, nurses had to be brought from Switzerland, from Denmark, from England because no trained French nurses of the right sort were to be had? (pp. 3-4)

Crowell (1919) suggested, however, that with additional training and supervision by an American nurse, the French Red Cross nurses could be employed to meet the Commission's urgent need for health visitors:

Numerous applications for work with the Commission had already been received from French Red Cross nurses who had had considerable experience in the military hospitals. To meet the immediate emergency ... it was decided therefore to accept the most promising of these applicants and to give them, as far as possible, the necessary training in dispensary and home visiting work while they were actually serving as members of the dispensary staff working under the direction of one of the American trained workers.

Thus, having agreed to accept Red Cross applicants into the Commission's dispensaries, Crowell, along with other CPTF officials, began to discuss the development of a regular training course for health visitors. The Commission was in favour of establishing its own training program, in addition to providing assistance to three Parisian schools to do the same (Crowell, 1919). According to Crowell, numerous conferences were held between the Commission's officials and the directors of these three training schools, and tentative programs, including both theoretical and practical components, were submitted for review by all parties (Crowell, 1919). However, Crowell quickly came to the view that the program should be abandoned:

[The] impossibility of securing the necessary supervision and training for pupils in the emergency American tuberculosis institutions that were being established by the Red Cross, the difficulty at that time of teaching in a foreign language by the medical staff, [as well as] the practical housekeeping considerations to be encountered, in finding and maintaining a nurse's home under the abnormal living conditions in Paris resulting from the war, were deciding factors against having a training school under the jurisdiction of the Commission. (Crowell, 1919)

Instead, the Commission provided each of the three Parisian schools with a number of scholarships to allow students who would not otherwise be able to afford the required time to train as health visitors to take part in this training. The conditions attached to these scholarships ensured that the Commission would be equipped with uniformly trained health visitors who would be available to staff any of the Foundation's dispensaries in France (Crowell, 1919). ${ }^{4}$ The number of scholarships provided to each of the three participating schools was determined by its facilities for practical experience, including the provision of competent supervision (Crowell, 1919).

To assist schools to meet these conditions, the Commission agreed to aid in the payment of supervisors' salaries, as well as accept any candidates selected by these schools to become supervisors for special training in the Commission's dispensaries. Finally, the CPTF also offered the use of its Paris dispensaries for practical training for as many pupils as possible from each school, and secured financial aid from the Red Cross for the installation and equipment of a dispensary in connection with one of the schools (Crowell, 1919).

\footnotetext{
${ }^{4}$ Another implication of these conditions was that the women who were awarded these scholarships were all single.
} 
The CPTF's first dispensary opened in Paris in October 1917. By December 1918, five training schools or centres for health visitors had been established, all conforming to a uniform scheme approved by the Commission (Crowell, 1919). To ensure proper supervision of the practical work of these students, the Commission accepted candidates appointed by the schools to act as supervisors for special training in their own dispensary. The Commission also aided in the payment of these supervisors' salaries (Crowell, 1919). Courses of either ten or six months' duration were offered to students, according to their previous training and experience (Crowell, 1919).

Perhaps because of her background in social work, in her first annual report, Crowell singled out the importance of the provision of relief by health visitors working with tubercular families: In short, it was absolutely essential that, if the medical work of the dispensaries was to be effective, it must be supplemented by a certain amount of relief in the homes (Crowell, 1919). This was a similar argument to that being made by nurse leaders in the United States in support of the development of a role for public health nurses. The US-based nurse leaders were arguing for the preparation of nurses who could simultaneously provide sick care to people in their homes and connect them to the required social services. However, Crowell noted the difficulties faced by the French health visitor in providing this relief, as compared to her counterparts in the United States, because of the lack of organized private agencies providing relief that were common in the United States, such as the Women's Clinic Auxiliaries and Charity Organization Societies. In terms of public relief agencies in France, Crowell reported that although these agencies were numerous in Paris, they were extremely lacking in resources (Crowell, 1919). Thus, to provide additional aid toward relief measures, the American Red Cross assisted in creating a fund for the Commission to use for families under dispensary care (Crowell, 1919).

In addition to the lack of a broader infrastructure supporting the practice of public health in France, Dr. Anna Hamilton, ${ }^{5}$ a French-trained physician, argued that the necessary foundation for the development of a public health nursing workforce, including both adequate bedside and visiting nurse training programs, was not yet available in France:

Public health work in the United States has grown out of visiting nursing, this visiting nursing was begun thanks to the hospital trained nurse. Where visiting nursing is nonexistent, public health work cannot be established. Therefore the greatest want of France is French trained nurses (after the American meaning of the word trained); their visiting nurse and last of all public health work. Establishing public health work first, would be like building most health quarters at the top of a very unsanitary tenement house, with no staircase to lead up to these healthy quarters, and then advise the poor tenants to go and live up there. (Florence Nightingale School of Nursing Bordeaux, )

Thus, numerous barriers prevented Crowell from developing a public health nursing workforce as nurse leaders in the Unites States were calling for. In addition to these social and educational

\footnotetext{
${ }^{5}$ Dr. Anna Hamilton began her medical training in Marseille and later completed her studies in Montpellier. During her studies, she completed her thesis on the reform of French hospital nursing. Hamilton rejected the claim that English and American styles of nursing education could not be implemented in France. Later during her leadership of a nursing school in Bordeaux, Hamilton drew heavily from the ideas of foreign reform efforts, hired foreigntrained leaders, and regularly interacted with the international nursing community. For more on Hamilton's career see Schultheiss (2001).
} 
barriers, Crowell received minimal support from Foundation officers in her preliminary efforts to improve the training of bedside nurses in France.

Despite not requiring health visitors to be fully trained nurses, Crowell was in fact committed to the continued training of nurses as health visitors, as was demonstrated by her commitment to the improvement of nursing education in France. After her initial survey, Crowell noted that bedside nursing education in France was poor and would negatively affect the Commission's efforts in the training of health visitors. ${ }^{6}$ However, Crowell did not receive the support of Foundation officers in her desire to further study the training of bedside nurses (Williams, 1919). Demonstrating a lack of understanding or support of the training of nurses as health visitors, Embree (1919) stated that the Commission was to remain focused on its primary role in public health and tuberculosis prevention, rather than broaden the scope of their work to include the training of bedside nurses:

The CPTF is engaged in a very specific piece of public health work. It seems very desirable to restrict the activities of the commission to (a) problems immediately concerned with the tuberculosis campaign and (b) those immediately affected by that campaign, as, for instance, the development of public health laboratories, training of health visitors, etc. ... . Considered then from the standpoint of the Foundation's general interest in health, we feel that we are not yet ready to take a part in the training of general bedside nurses.

Crowell continued her efforts to supplement existing nursing programs in France to better prepare these women for health visiting work:

Nurses' training schools in the sense that we understand the term, are so few as to be practically non-existent so that their graduates are a negligible source of supply for candidates for admission to these specialized training centres for public health workers. The Commission has endeavoured to fill in this gap, by supplying to these training centers fully trained American or English nurses as . . . hoping thus to teach them the bedside care of the sick as we understand it, and thus prepare them to care for emergency cases which they might encounter later on in the home visiting work. (Commission for the Prevention of Tuberculosis in France, 1919)

As the Commission's training standards remained relatively high, a new problem quickly arose for Crowell: the demand for trained health workers increased far more rapidly than the supply (Division of Public Health Visiting, 1920). In Crowell's opinion, one of the greatest difficulties in furnishing the necessary supply was the difficulty in recruiting suitable candidates. In particular, she complained that the $37 \%$ attrition rate of the training centres was too high, and was a result, in her opinion, of a rather careless choice of candidates (Division of Public Health Visiting, 1920). Crowell was confident, however, that the attrition rate would fall as the leaders of the nursing schools became more familiar with the qualifications and training necessary for health visitors (Division of Public Health Visiting, 1920).

By the end of 1920, the CPTF had trained 153 health visitors who were then working in 136 French dispensaries, including those established outside of Paris in Lyons, Lille, Bordeaux, Nantes, and Marseilles (Bureau of Public Health Visiting, 1921). Crowell believed that the

\footnotetext{
${ }^{6}$ Ironically, in 1920 the Committee on Nursing Education was requested to expand its study beyond public health nursing education to also include the study of bedside nursing education, recognizing the relationship between the two.
} 
Commission had achieved much in the name of nursing and public health in France by this time: "The experience of the last year has demonstrated one fact beyond cavil or doubt - that the trained public health worker, the health visitor, call her what you will, has come to stay in France" (Bureau of Public Health Visiting, 1921). She also described how the French public had gained a better understanding of the need for well-educated and trained health visitors:

The French people, that portion of them which is beginning to think in terms of public health, whether they be governmental agencies or individuals supporting private organizations, have in the main accepted our conception of a professional paid worker who shall be an educated, cultured woman, une dame, specially trained for health work, as an indispensable factor in any public health activity which bases its program on preventive, educational work in the homes. What is still more significant, they are willing to pay for her, to give her a fair living wage; this is surely the acid test of their sincerity, of their final conviction! (Bureau of Public Health Visiting, 1921)

A sign of the acceptance of these workers in France, according to Crowell, was the fact that they were being paid, in part, by local French authorities (Bureau of Public Health Visiting, 1921, p. 1). ${ }^{7}$ With this support from the public, Crowell argued that nurses in France were provided with an opportunity for an expanded career and new-found legitimacy for their role in preventive care (Bureau of Public Health Visiting, 1921).

Admittedly, however, Crowell stated that the Commission's training programs, although strong on theory, were still weak in the area of practice, because of the lack of proper facilities for institutional training available in France (Bureau of Public Health Visiting, 1921). Despite the success of the newly trained French health visitors on the anti-tuberculosis campaign, as well as on the more general public health campaign, Crowell remained fixated on improving and standardizing the training of these workers (Bureau of Public Health Visiting, 1921).

As a result of these improvements, by 1920, the six-month training course had been practically eliminated, except in the case of extraordinary candidates who had evidence of previous preparation in health visiting. Thus, over the course of two years, the 10-month course in health visiting (primarily in the areas of tuberculosis and children's work), preceded by one year of general hospital experience, had become the standard of training for health visitors in France (Bureau of Public Health Visiting, 1921). Crowell admitted, however, that the weak point remaining within this system of training for health visitors was the first year of hospital training then available in France:

Nurses' training schools in the sense that we understand the term, are so few as to be practically non-existent so that their graduates are a negligible source of supply for candidates for admission to these specialized training centres for public health workers.56

Crowell looked for further solutions to improve bedside nursing education. She questioned whether it would be possible to develop a combined training program that would work toward the improvement of both bedside nursing within hospitals and the training of health visitors.

In an attempt to answer this question, Crowell formulated a bifurcated program aimed at the training of both bedside nurses and health visitors. The course was two years in duration, with the first year common to both groups and composed of general hospital training in medical and

${ }^{7}$ Of the 153 trained health visitors then working in French dispensaries, 96 were receiving their salaries from French committees rather than the CPTF. 
surgical wards for adults and children. The second year was elective, consisting of additional work in medical wards, operating rooms, and general dispensary service for those pupils desiring to obtain a diploma for bedside or visiting nursing (see Figure 1). Specialized training in tuberculosis, children's services, school hygiene, and social service could be arranged for those pupils who desired to work toward a diploma for public health visitors (Bureau of Public Health Visiting, 1921).

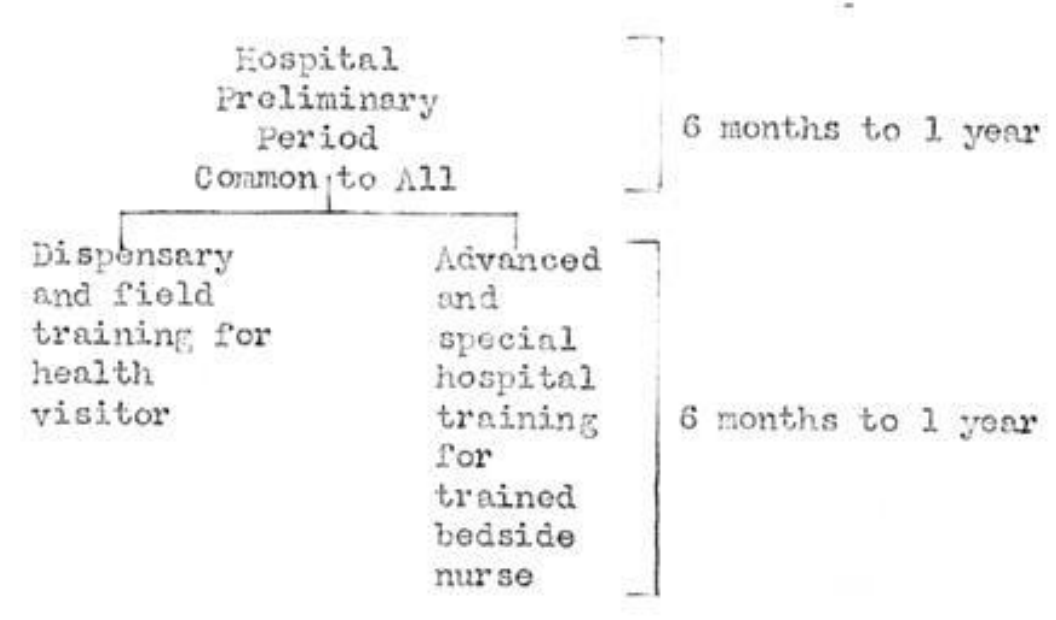

Figure 1 Two-Year Bifurcated Program as Developed by Crowell

The first course based on the bifurcated program was established at the University of Strasbourg in 1921, with graduates receiving a diploma granted by the University's Faculty of Medicine (Bureau of Public Health Visiting, 1921). The granting of university status to the course raised its prestige and placed admissions criteria at a fairly high level. The program of study became known as the bifurcated course or the Strasbourg Plan, and was implemented in a second French city, Nancy, soon after. In June 1922, Crowell wrote to George Vincent, president of the $\mathrm{RF}$, telling him that the Strasbourg plan was gaining popularity throughout Europe: "It seems worthy noting that what we have already done at Strasbourg is having an influence outside of France, and that in Czechoslovakia, for instance, one hears frequent reference to the Strasbourg plan as a scheme worthy of serious consideration" (Vincent, 1922). However, although Crowell's bifurcated program was more comprehensive than the existing Red Cross training programs for home visitors, in the eyes of nurse leaders in the United States, the program still paled in comparison to similar programs offered in North America. In actuality, Crowell's bifurcated program was not unlike early plans for the training of public health officers in the United States. William Sedgwick, a professor at the Massachusetts Institute of Technology had himself proposed a Y Plan of medical education outlining a common first two years of education for medical students, with the upper years diverging, one arm leading to the degree of doctor of medicine, and the other to the doctor of public health (Fee, 1987, p. 25).

In July 1922, a national nursing regulation was passed in France that required nurses to complete two years of training in a recognized school. At the same time, France's minister of hygiene created the conseil de perfectionnement, a national committee consisting of two branches: one for bedside and hospital nurses, the other for health visitors (not unlike the nursing committees established under the National Council of Defense in the United States in 1917). The members of 
the committee included men and women most interested in the development of nursing work, including the directors of the training programs established in Strasbourg and Nancy, based on Crowell's bifurcated program (Adams, 1923). Shortly after it was formed, the conseil de perfectionnement set out to prepare a standard curriculum and study existing schools, recommending state recognition for those that conformed to the provisions of the 1922 state regulation (International Health Board Nursing and Health Visiting, 1924). However, as Schultheiss (2001) has argued, although the 1922 regulation provided nursing education in France with added legitimacy, the diploma was not required to practise nursing, and schools were not required to conform to the established standards.

Without consensus on the training of public health workers, the CPTF's continued role in the training of health visitors under the direction of Elisabeth Crowell continued to be debated by American-based nurse reformers, in particular Annie Goodrich, then dean of the Army School of Nursing. Although Crowell too was critical of the CPTF's training program, describing it as ostrich-like-ignoring the connection between improving preliminary training programs for nurses and the training of health visitors-Goodrich deplored Crowell's practical, incremental approach to improving the training of nurses in France. However, despite this criticism, Crowell was successful in raising both the standard of nursing education and the public image of the nurse during this period.

Back on US soil, by February 1923, after five years and \$55,000, the report of the Committee on Nursing Education, known most commonly as the Goldmark Report, was published under the name of Nursing and Nursing Education in the United States by the Macmillan Company (the report had been finished much earlier, and in June 1922 had been presented at a nurses' convention in Portland, as well as to the Biennial Convention of the nursing groups in Seattle).

The final report was published in two sections: I. The Functions of the Nurse, and II. The Training of the Nurse. The first section included subsections covering public health nursing, private duty nursing, and nursing in institutions. The second section covered the hospital school of nursing, training courses for subsidiary nursing groups, the university school of nursing, and postgraduate courses. The Committee's aim was to settle the debate between the two types of public health visitors then in existence: one in which the visitor confined herself to the teaching of hygiene, and the other in which such instructive work was combined with the actual care of the sick:

We have attempted, therefore, to survey the entire field occupied by the nurse and other workers of related type; to form a conception of the tasks to be performed and the qualifications necessary for their execution; and on the basis of such a study of function to establish sound minimum educational standards for each type of nursing service for which there appears to be a vital social need. (Goldmark, 1923, p. 7)

The public health nurse was defined in the report as "any graduate nurse who served the health of the community, with an eye to the social, as well as the medical aspects of her function, by giving bedside care, by teaching and demonstration, and by guarding against the spread of infections, unsanitary practices, etc." (Goldmark, 1923).

The primary findings of the study included the recommendation that all nursing schools include the completion of high school education as an entrance requirement for pupils, and that all public health nurses be required to first complete a formal program of study in bedside nursing, supplemented by a graduate course in public health nursing. The Committee on Nursing's findings 
provided further fuel for US nurse leaders' arguments against continued claims for non-nurse health visitors. Other major recommendations from the Committee's study included higher admissions standards and shorter periods of higher-quality education for all nurses.

The success of the Committee's report in reforming nursing education in the United States has been debated by scholars such as Susan Reverby (1987), who has argued that the report only reflected the views of a few elite members of the profession. Copies of the Goldmark Report were distributed widely, including to international organizations such as the International Council of Nurses and the League of Red Cross Societies, as well as to each member of the Rockefeller Foundation (Embree, 1923; Goldmark, 1923). Even before it was published, a copy of the report was also sent to Crowell in July 1922, with a request that she disseminate it more widely in Europe (Stoughton, 1922). Nearly a month later, Crowell responded to Vincent's request, arguing against the applicability of study's findings outside the United States:

Following Dr. Vincent's suggestion, I am having this translated into French for very limited distribution. The conditions here and in other continental countries are so very different, the conception of professional training for hospital nurses and public health workers is so new, that I am a bit fearful of the effect this report might produce; it might be more confusing and upsetting than helpful. (Crowell, 1922a)

Crowell did, however, request additional copies for several English colleagues:

I should like to have quite a few additional copies if you will be good enough to send them to me, say a couple of dozen, if you have them already mimeographed [sic] and on hand; or if you prefer, I can have the copies made here. I would like very much to use them amongst some of our English friends, and amongst certain other English speaking continentals who are thoroughly familiar with the nursing situation in the United States and England. (Crowell, 1922a)

In November 1922, Crowell received a letter from Lord Knutsford, chairman of the London Hospital House Committee in England, expressing his seeming outrage over the report. His response epitomizes the polarization of opinion between the English and US nursing leaderships regarding nursing education. It is thus worth quoting at length:

I am dismayed at the Report of the 19 ladies and Gentlemen who have reported to the Rockefeller Foundation on Nursing. . . . if I am ill may God save me from being nursed by the ideal nurse that report sets up. With all respect to the writers they seem to me to confuse Public Health nurses or rather Inspectors with the nurse whose duty is to do the actual nursing of the sick person under the orders of the doctor. For the Public Health Nurse all the learning and study and knowledge they foreshadow and recommend is, I daresay, necessary. But it is not necessary for the nurse attending a patient. And I go so far as to think that sick nurses, by that I mean nurses attending the sick are better without all that learning. If they have it they might easily fall upon themselves to be critics of treatment and would not be adaptable to the surroundings of the homes where they had to nurse the sick. If all this learning is required of every young woman who feels a call for nursing, a call, which many a good woman feels you will put a ... serious limitation on the number of women who can enter the profession. (Knutsford, 1922)

Lord Knutsford's letter highlights a common belief (which still persists today) that the overeducation of nurses would serve as a detriment to patient care. Furthermore, his letter suggests the 
continued misunderstanding regarding the role of public health nurses as both providers of sick care and educators of disease prevention and health promotion. He continues by remarking on the Committee's suggestion that nursing education be removed from the hospital to better serve the needs of the nurse:

The Report rather sneers at the teaching in Hospitals. . . . My blood rather boils over at the words "the training is sure to suffer in having to give way to the needs of the sick." Why I always thought that the need of the sick was the dominating inspiration which makes a woman give up her life to nursing ... the training of the nurses [seems] to be of more importance than the care of the sick. I have said enough. Somehow I do not see you agreeing with that report. (Knutsford, 1922)

The report's focus on the promotion of higher education and continued professionalization, including the movement of nursing education within educational institutions, was counter to the philosophy of duty and devotion to care then prominent in England, and was thus met with skepticism over its applicability outside North America.

In her response to Knutsford, Crowell—although sympathetic to his opinion-expressed her support for the work of the Committee for Nursing Education. Crowell argued in support of her American colleagues' disapproval of the exploitation of nursing students within hospital-based training programs:

I fully appreciate your reaction to what at first sight appears a failure to give due prominence to the needs of the sick in hospitals. ... It seems to me that the training of nurses, sick nurses or others, is one thing, and the securing of an adequate, efficient hospital personnel is another, and that our difficulties to day, both in America and England, are the result of our training to perpetuate a system which has outgrown the times and the needs that gave it birth. ... That training has so far provided a wonderful hospital personnel, but the individual has been sacrificed to the system. Three years, four years are being used to teach her what she should have been taught in two years if her training had been planned with an eye to her interests, instead of those of the hospital which is unwilling to pay an adequate, permanent staff. (Crowell, 1922b)

Following this, however, Crowell shared her belief that her US colleagues' approach to this issue had placed too much emphasis on the development of the profession, to the detriment of the care of the sick. At the same time, Crowell also questioned the methods of nursing education then present in the United Kingdom:

I am quite willing to admit that for some years I have felt that in America there has been a tendency to overemphasize the development of a profession for women, with the care of the sick as a corollary thereto-but I also believe that in England the converse is true; that the care of the sick has been the paramount experience during the last five years. ... The thought came to me not long ago, after my recent visits to Czechoslovakia and Italy where there is a vociferous demand for a clear demarcation between the functions of a servant and a nurse if a better type of woman is to be attracted to hospital service, that in those countries they have servants doing nursing work, while in England they have nurses doing servants' work. (Crowell, 1922b)

In a letter to Annie Goodrich, Crowell's assistant, Gladys Adams highlighted the differing philosophies in Europe and the United States regarding the separation of nursing education from 
the hospital, and the resulting difficulties of imposing an American method of nursing education and practice in Europe:

It seems to me that the tendency in America at the present time is to separate the school of nursing from the hospital administration. I can see all the points relating to the past exploitation of the nurse and recognize that the hospital administration has benifitted [sic] too much by it. On the other hand, over here where the school is an entirely separate entity, there are again difficulties: the theory can be worked out excellently, the practical work is limited, I admit, and not perfected, but to me the thing that is most lacking is the sense of responsibility towards the patients and the work. So when I read of the new development, I am wondering if in making the adjustment, we will not lose that sense of duty and responsibility so important. To me the education of the nurse not only depends on her theory and her practice, but much more abstract than that, her sense of conscientious duty and devotion. Will that be lost? (Adams, 1923)

In the minds of the nurse leaders of the US nursing organizations, such as Annie Goodrich, Adelaide Nutting, and Mary Beard, Crowell's education and experience was inferior to their own, and inferior to the standards they promoted in their reform efforts. According to nurse historian Sarah Abrams (1992), Annie Goodrich in particular was highly critical of Crowell's work. Goodrich felt that Crowell was making it difficult to raise nursing standards and attributed Crowell's approach to training and the profession in general to her own training at a Catholic hospital school with a poor reputation. French historian Pierre Yves Saunier has also suggested that Crowell's education within Catholic schools and her continued religious practices created a sharp division between her and her US colleagues. Saunier (2008) suggests that at this time, nurse leaders in North America considered religious nurses as the epitome of the untrained, submitted and archaic, and Crowell was one of them. In addition, Crowell's practical decision to accept minimally trained nurses into health visitor training programs was in direct opposition to the beliefs of American nurse leaders such as Annie Goodrich, who was working to oppose the use of minimally trained nurses and non-nurse health visitors in the United States.

Crowell maintained her commitment to a local approach and advocated once again for the development of more than one school in each country, particularly where diverse ethnic groups or varying educational needs were present. By 1925, Crowell had found allies in this regard at the University of Toronto Department of Public Health Nursing, Kathleen Russell and Jean Gunn.

After completing a tour of Europe, funded by the Rockefeller Foundation, Kathleen Russell reported again having been impressed with the local effort throughout those countries visited, noting that, no matter the existing conditions in nursing, the idea of better nursing was forefront in the minds of those in charge. Russell also argued that North American nurses could learn a lot from every country in Europe, and cautioned against the formation of an attitude of unconscious superiority and condescending benevolence (Vincent, 1925).

Regarding the Foundation's policy in nursing education, both Russell and Gunn agreed that the policy currently being promoted (i.e., that of steady progress, following the work that had been done in France) was sound and progressive. They expressed their belief that to raise the standards any further would mean an end to the Foundation's work. Both Russell and Gunn emphatically approved of the work of Crowell, whom they believed demonstrated wise judgment and leadership. Like Crowell, Russell and Gunn argued that various countries must be allowed to work out their own systems of nursing, rather than an outside agency even appearing to be 
imposing a standard from without (Russell, 1925). Russell expressed her hope that the development of nursing throughout Europe would follow the necessary form required to meet the specific needs of each country:

nursing education and organization will develop variously in the different countries of Europe, probably showing a wide variety of form and procedure. At least it is greatly to be hoped that such will be the case.

In October 1925, the Foundation voted to enact changes to their European Nursing program, aiming for the creation of lighthouse institutions that would set benchmarks in education, rather than address the immediate needs of the population. This resolution marked a significant shift in the Foundation's aims in Europe, from supporting the development of nursing schools and the preparation of rank-and-file nurses, to the sole preparation of leaders, teachers, and administrators in the profession. The Foundation's decision to move away from supporting the development of multiple nursing schools and instead focus on the training of leaders in the profession resonated with the work of nurse leaders in the United States.

Crowell's work throughout the following year (1926) continued to be limited by the Foundation's new policy of limiting aid to one school per country, as well as insisting upon a higher standard of applicant and training. Although she was able to help lend support to the development of additional nursing programs in Czechoslovakia and Hungary, aid to these programs was only approved because it was felt that certain commitments had already been made prior to the new policy being enacted (Crowell, 1926). The Foundation did not want to embarrass those projects already underway and thus agreed not to pull out of any of its agreed-upon programs. It was with this understanding that the Foundation agreed to maintain its funding toward schools in Hungary and Poland (Crowell, 1926).

The delay in funding decisions caused by the events of the fall of 1925 led to further complications for some European nursing schools that were depending upon Foundation support. For example, in her master's thesis examining Crowell's work in Czechoslovakia, Elizabeth Vickers (1996) argues that the delay in the Foundation's commitment to fund the Prague School of Nursing resulted in Czechoslovak officials having to renew their contract with the Red Cross to administer the school for another year. Thus, the Foundation's decision to revise its policies at the October conference ironically allowed for the continuation of schools it deemed substandard.

The debates between Crowell in the Paris office and the nurse leaders in the United States can be understood as representing conflicting philosophies over the education and training of nurses, and the role of US agencies in this training within other countries. On the one hand, there was the view espoused by Crowell, and endorsed by Russell and Gunn in Toronto, that the wisest plan was to support the development of a European approach to building public health nursing education that was sensitive to local conditions and created in collaboration with local nursing leadership. On the other hand, there was the approach of the US-based nurse leaders, to create programs that promoted the professionalization of public health nursing in ways that matched the ideals of the Foundation. In this latter approach, the goal was to set the highest benchmarks in education and build a cadre of leaders who met that standard of excellence, as well as to carve out a leadership position for the Foundation in nursing education globally. The decision by RF president George Vincent, in October 1925, to draw a sharp line between these conflicting philosophies placed preference on the American based nurse leaders, leaving Crowell's plan to fall by the wayside. A secondary consequence of this decision was a sharp limitation of support to 
nursing programs that did not meet the Foundation's standards, particularly those under the auspices of the Red Cross, the primary provider of nursing education in Europe during World War I. Crowell remained committed to an agenda of improving the education of nurses throughout France. However, her approach to this agenda was based on local need rather than a professional ideal. 


\section{References}

Abrams, S. (1992). Dreams and awakenings: The Rockefeller Foundation and public health nursing education, 1913-1930 [Unpublished doctoral dissertation]. University of California.

Adams, G. (1923, October 5). [Letter to Annie Goodrich]. Rockefeller Foundation Archive, Rockefeller Archive Center (Folder 97, box 9, series 500, RG 1.1), Sleepy Hollow, NY, United States.

Braybon, G., \& Summerfield, P. (1987). Out of the cage: Women's experiences in two world wars. Pandora Press.

Bullough, V. L., \& Sentz, L. (Eds.). (2000). American nursing: A biographical dictionary (Vol. 3). Springer.

Bureau of Public Health Visiting. (1921). Annual report Bureau of Public Health Visiting 1920. Rockefeller Foundation Archive, Rockefeller Archive Center (Folder 272, box 30, series 500C, RG 1.1.), Rockefeller Foundation Archive, RAC.

Commission for the Prevention of Tuberculosis in France. (1919). Report of the work of visiting nursing staff of the Commission for the Prevention of Tuberculosis in France from August 1917 to December, 21, 1918. Rockefeller Foundation Archive (Folder 269, box 29, series 500C, RG 1.1), Rockefeller Archive Center, Sleepy Hollow, NY, United States.

Crowell, E. (1922a, August 4). [Letter to Stroughton]. Rockefeller Foundation Archive, Rockefeller Archive Center (Folder 137, box 19, series 700, RG1.1), Sleepy Hollow, NY, United States.

Crowell, E. (1922b, November 20). [Letter to Lord Knutsford]. Rockefeller Foundation Archive, Rockefeller Archive Center (Folder 419, box 33, series 401C, RG.1.1), Sleepy Hollow, NY, United States.

Crowell, E. (1926, July 16). [Letter to Edwin Embree]. Rockefeller Foundation Archive, Rockefeller Archive Center (Folder 140, box 29, series 700C, RG.1.1), Sleepy Hollow, NY, United States.

Crowell, F. E. (XXXX). Nursing education and hospital service in France. Rockefeller Foundation Archive (Folder 100, box 9, series 500, RG 1.1), Rockefeller Archive Center, Sleepy Hollow, NY, United States.

Crowell, F. E. (1919). Report on the work of visiting nursing staff of the Commission for the Prevention of Tuberculosis in France, from August 1917 to December 31, 1918. Rockefeller Foundation Archive (Folder 269, box 29, series 500, RG 1.1), Rockefeller Archive Center, Sleepy Hollow, NY, United States.

Division of Public Health Visiting. (1920). Annual report of the Division of Public Health Visiting from January 1st, 1919 to December 31st, 1919. Rockefeller Foundation Archive, Rockefeller Archive Center (Folder 270, box 29, series 500C, RG 1.1.), Sleepy Hollow, NY, United States.

Donner, H. (1997). Under the cross - Why VADs performed the filthiest task in the dirtiest war: Red Cross women volunteers, 1914-1918. Journal of Social History, 30(3), 687-704. 
Embree, E. (1918, July). Officer's diary. Memo: Family Journal No. 1, July 1918. Rockefeller Foundation Archive (RG 12.1), Rockefeller Archive Center, Sleepy Hollow, NY, United States.

Embree, E. (1919, September 23). [Letter to Linsly R. Williams]. Rockefeller Foundation Archive, Rockefeller Archive Center (Folder 97, box 9, series 500C), Sleepy Hollow, NY, United States.

Embree, E. (1923, February 23). Diary. Rockefeller Foundation Archive (Folder 328, box 38, series 100. R.G.1.1), Rockefeller Archive Center, Sleepy Hollow, NY, United States.

Fee, E. (1987). Disease and discovery: A history of the Johns Hopkins School of Hygiene and Public Health, 1916-1939. Johns Hopkins University Press.

Florence Nightingale School of Nursing Bordeaux. (XXXX). Rockefeller Foundation Archive (Folder 101, box 10, series 500, RG.1.1). Rockefeller Archive Center, Sleepy Hollow, NY, United States.

Goldmark, J. (1923). Nursing and nursing education in the United States: Report of the Committee for the Study of Nursing Education and report of a survey. Macmillan Company.

International Health Board Nursing and Health Visiting. (1924). Annual report, 1923. Rockefeller Foundation Archive (Folder 97, box 9, series 500C, RG 1.1), Rockefeller Archive Center, Sleepy Hollow, NY, United States.

Knutsford, L. (1922, November). [Letter to Elisabeth Crowell]. Rockefeller Foundation Archive, Rockefeller Archive Center (Folder 419, box 33, series 401C, RG.1.1), Sleepy Hollow, NY, United States.

Murard, L., \& Zylberman, P. (2000). Seeds for French health care: Did the Rockefeller Foundation plant the seeds between the two world wars? Studies in History and Philosophy of Science, 31(3), 463-475.

Reverby, S. (1987). Ordered to care: The dilemma of American nursing, 1850-1945. Cambridge University Press.

Rockefeller Foundation. (1921, February 23). Minutes of the Rockefeller Foundation, Feb. 23, 1921. Rockefeller Foundation Archive (Folder 137, box 19, series 700, RG.1.1), Rockefeller Archive Center, Sleepy Hollow, NY, United States.

Russell, R. (1925, September 23). [Letter to Edwin Embree]. Rockefeller Foundation Archive, Rockefeller Archive Center (Folder 139, box 19, series 700C, RG.1.1), Sleepy Hollow, NY, United States.

Saunier, P. Y. (2008, October 2-3). Rockefeller nursing fellowships: Policies and usages, 19151940 [Workshop presentation]. Foundations, Fellowships and the Circulation of Knowledge in the 20th Century: A Transnational Perspective, Rockefeller Archive Center, Tarrytown, NY, United States.

Schultheiss, K. (2001). Bodies and souls: Politics and the professionalization of nursing in France, 1880-1922. Harvard University Press. 
Stoughton. (1922, July 12). [Letter to Elisabeth Crowell]. Rockefeller Foundation Archive, Rockefeller Archive Center (Folder 137, box 19, series 700, RG1.1), Sleepy Hollow, NY, United States.

Summers, A. (1988). Angels and citizens: British women as military nurses. Taylor and Francis.

Vickers, E. (1996). Frances Elisabeth Crowell: An evaluation of a European nursing experience [Unpublished master's thesis]. University of West Florida.

Vincent, G. (1922, June 17). [Letter to Elisabeth Crowell]. Rockefeller Foundation Archive, Rockefeller Archive Center (Folder 1s37, box 19, series 700, RG.1.1), Sleepy Hollow, NY, United States.

Vincent, G. (1925). Officer diary, George Vincent. Memorandum of a Conference with Miss E. K. Russell, Director of Public Health Nursing, Toronto, Department of Hygiene, and Miss J. I. Gunn, Superintendent of Nurses, Toronto General Hospital; revised after submission to Miss Russell and Miss Gunn, Toronto, September 18, 1925.

What is a nurse? (1911-1915). Red Cross (December-January).

Williams, L. R. (1919, August 8). [Letter to Edwin Embree]. Rockefeller Foundation Archive, Rockefeller Archive Center (Folder 97, box 9, series 500, RG.1.1), Sleepy Hollow, NY, United States. 